\title{
Municipal Waste-to-Energy plants in Poland - current projects
}

\author{
Maciej Cyranka ${ }^{1, a}$, Michał Jurczyk ${ }^{1}$ and Tadeusz Pająk ${ }^{1}$ \\ ${ }^{1}$ Department of Power Engineering and Environmental Protection, AGH University of Science and Technology, Krakow, Poland
}

\begin{abstract}
In 2016, six new municipal waste combustion plants will be operating in Poland. These projects, located in: Białystok, Bydgoszcz, Konin, Kraków, Poznań and Szczecin, will influence waste management in Poland as well as change energy security of the country. So far in Poland only one Waste-to-Energy (WtE) plant, i.e. in the capital city of Warsaw, has been operating. Unfortunately, this is not enough, taking into account Polish economic development in the last years. Polish accession to the European Union (EU) significantly influenced the development of the industry which resulted in increased production of waste while the management system was not prepared to handle it in the proper way so there was a big amount of waste. The main way to deal with waste in Poland was, and still is, landfilling which can be in many ways dangerous for the environment. The EU law have put pressure on Polish Waste Management Systems and results are visible in currently realized Waste-to-Energy projects.

This work analysis of the aforementioned 6 projects from economic (project value, funding from the European Union) and technological (used technology, waste throughout, availability etc.) point of view together with their impact on the entire waste management system and energy security. What is more, history of similar facilities in Poland is presented, what shows how many projects were prepared, how many fell through and time frame of finally realised projects (start of construction and the planned completion).

Conclusions show why in the current situation development of Polish WtE infrastructure is right, i.e. operation of aforementioned plants that will ensure benefits associated with energy production, reduction of landfilling and informing public opinion regarding modern waste management models. Additionally, the article draws attention on the high responsibility that will be put on WtE plants operators and that experience gained during WtE implementation can be used to improve even further for future Polish Waste Management Systems.
\end{abstract}

\section{Introduction}

The amount of generated municipal waste is increasing, while European Union (EU) environmental requirements are becoming stricter, forcing the Polish government apparatus to implement reliable and effective waste management programmes. Poland through ratifying the EU Accession Treaty in 2003 oblige itself to pursue a number of commitments in the field of municipal waste management, from which most important are [1]:

- Reduction of municipal waste landfilling;

- Increase of waste recycling levels;

- Reuse of certain waste fractions.

Unfortunately, Polish waste management essentially relies on the waste landfilling, which is a highly unfavorable and undesirable process in terms of suitable development and resource efficiency. In 2014 approx. 10330 thousand tons of municipal waste were collected in Poland, of which approx. 5835 thousand tons $(56.5 \%$ of waste collected in total) were disposed by landfilling or thermal processing without energy recovery [2].

Without any doubt chemical energy contained in municipal waste, instead of wasting on landfills, should be used to produce usable forms of energy. EU impose duties in that matter by Directive 2008/98/WE [3], which

${ }^{\mathrm{a} C}$ Corresponding author: cyranka@agh.edu.pl states that all Member States shall take appropriate measures to establish an integrated, modern and proportioned network of facilities for the municipal waste recovery or recycling. Directive 2008/98/WE [3] sets the conceptfor EU Member States waste legislation and policy which they shall apply as a priority order, which is shown symbolically on Figure 1.

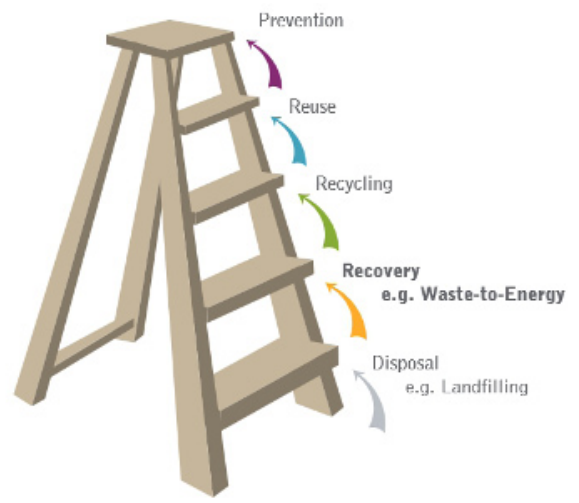

Figure 1. The waste hierarchy [4]. 
According to Figure 1 the first step of municipal waste treatment should be re-use or recycling and next energy recovery in Waste-to-Energy (WtE) plants. However, it can be assumed that the development of energy recovery infrastructure contributes also to the development of recycling. Some examples are confirming that communities supplying municipal waste to $\mathrm{WtE}$ facilities generally have higher than the average recycling rates [5] [6]. In countries with advanced waste treatment systems (like Germany or Sweden) the WtE infrastructure is an integrated part of the waste management system. Therefore, WtE may be regarded as the natural and necessary step of countries, like Poland, going from landfilling towards higher levels in the waste hierarchy [7].

Energy recovery from municipal waste is carried out primarily by combustion processes, which are conducted in special industrial objects called WtE plants (or MSWI Municipal Solid Waste Incinerators). Combustion of fossil and biofuels provides more than $90 \%$ of the world's energy [8], therefore it is not surprising that this type of thermochemical conversion process is mostly used for energy production from municipal waste. The technical basis of energy recovery from municipal waste combustion, is to use generated thermal energy embedded in flue gases to produce steam at high temperature and pressure. Then, such steam is used to drive a turbine generator and/or for heating purposes. Maximizing the use of energy contained in every fuel, that is also in municipal waste, is currently recommended by international law energy economy model.

Designs of present WtE plants are developed with consideration of numerous criteria related not only with plant energy efficiency but also with impact on the environment, operational costs and available optimization possibilities. Modern WtE facilities that are equipped in advanced systems for waste processing, environmental control, and materials recovery, maintain both high energy efficiency and pollutants emission below EU and regional limits. Moreover, modern plants are able to increase recycling rates and yield residuals (i.e. fly ash, bottom ash, slag, and flue gas cleaning residues) with properties suitable for beneficial reuse, like for example as an aggregate material [5]. However, residuals conditioning can be expensive and because of that comparison analysis of environmental and economic aspects is needed.

The issues of energy, environment, and fuel resources are of great current interest and they have strong and important intersections, with each other and with the field of combustion [8]. Therefore, municipal waste combustion is highly related with aforementioned areas and it turns out that for each of them it brings a number of benefits. Those benefits are described later in this article, mainly on basis of Polish economy example.

\section{Present and Past Polish WtE Structure}

By the end of 2015 in Poland only one WtE plant has operated, i.e. "ZUSOK" plant in Warsaw, which was built in 2001. Warsaw is the capital and largest city in Poland
(1.74 million people [9]) and one of the fastest growing urban centers in the country. In 2014 around 520,7 thousand $\mathrm{Mg}$ of municipal waste was collected in this city [10], while the average amount of waste treated in "ZUSOK" is equal to approx. 40 thousand $\mathrm{Mg} /$ year [11], what gives $7,7 \%$ of waste collected in the Polish capital. Therefore, the current performance of only one WtE plant has a minimum importance in terms of the whole country. Meanwhile, it is predicted that Poland should take into account the needs of even 20-35 new facilities of such type [12]. While in 2011 the total number of WtE plants in the 18 European countries was 455 , and in the United States 86 [13].

Newly built WtE plants or those which are currently in the initial phase of operation, i.e. Białystok, Bydgoszcz, Konin, Krakow, Poznań and Szczecin (see Figure 2), due to their scale and the potential impact on the environment, are today one of the most important Polish investments in the environmental protection sector. At the same time the number of planned new $\mathrm{WtE}$ investments reaches up to 30 plants, but their estimated total capacity (i.e. approximately 3.8-3.9 million $\mathrm{Mg} / \mathrm{year}$ ) is rather still too small to achieve the planned 2020 reduction in the weight of landfilled biodegradable waste (i.e. 65\% weight reduction compared to the year 1995) [14].

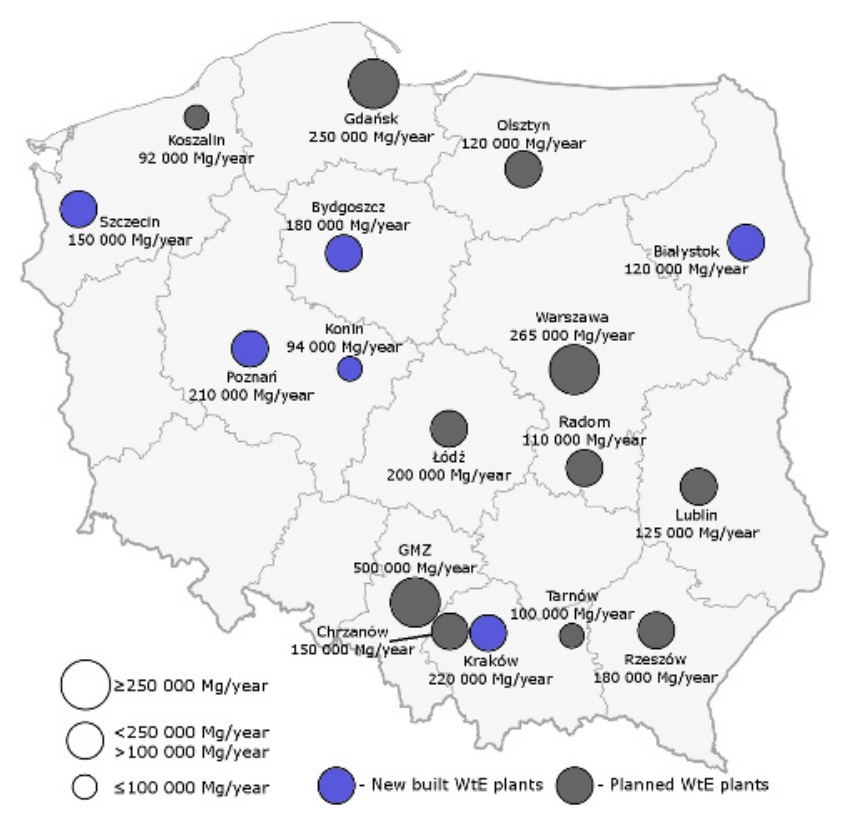

Figure 2. Polish WtE plants projects.

All WtE plants shown in the Figure 2 are intended for medium and large cities, what is an appropriate decision for location of this type of facilities. It is so because municipal waste generation rates are lower in rural areas since, on average, residents are usually poorer, purchase fewer goods, and have higher levels of reuse and recycling [15]. In addition, location of WtE plants in the big cities extends the capabilities of the energy distribution (especially generated heat) and makes it easier 
to obtain appropriate quality and quantity of municipal waste.

Nearly half of municipal waste in Poland (45.2\% in 2008) is generated in big cities with more than 50 thousand inhabitants [16]. Composition of waste originating from such areas is shown in Table 1.

Table 1. Municipal waste composition in Polish big cities.

\begin{tabular}{|c|c|c|}
\hline $\begin{array}{c}\text { Place of waste } \\
\text { generation }\end{array}$ & $\begin{array}{c}\text { Big cities } \\
\text { generally }\end{array}$ & $\begin{array}{c}\text { City of } \\
\text { Kraków }\end{array}$ \\
\hline Year & 2008 & 2003 \\
\hline Source & {$[16]$} & {$[17]$} \\
\hline Type of waste & & \\
\hline Paper and cardboard & $19,1 \%$ & $10,2 \%$ \\
\hline Multi-material waste & $2,5 \%$ & $3,1 \%$ \\
\hline $\begin{array}{c}\text { Kitchen and garden } \\
\text { waste }\end{array}$ & $34,2 \%$ & $40,6 \%$ \\
\hline F ine fraction $<10 \mathrm{~mm}$ & $4,2 \%$ & $8,5 \%$ \\
\hline Textiles & $2,3 \%$ & $2,7 \%$ \\
\hline Wood & $0,2 \%$ & $0,9 \%$ \\
\hline Glass & $10,0 \%$ & $10,1 \%$ \\
\hline Metals & $2,7 \%$ & $1,8 \%$ \\
\hline Plastics & $15,2 \%$ & $12,1 \%$ \\
\hline Mineral waste & $3,2 \%$ & $5,6 \%$ \\
\hline Hazardous waste & $0,7 \%$ & $0,2 \%$ \\
\hline Other categories & $5,8 \%$ & $4,1 \%$ \\
\hline Total municipal waste & 5,47 & 239.1 \\
millions $\mathrm{Mg}$ & $\mathrm{kg} / \mathrm{citizen} / \mathrm{year}$ \\
\hline
\end{tabular}

Research results regarding municipal waste composition and quantities in Polish big cities recently indicate great variability. This is so mainly because of various regimes with different areas and periods of sample collection [17]. However, on the basis of data from $\mathrm{Tab}$ 1. we can assume that $\mathrm{WtE}$ plants operating in large Polish cities will be supplied with appropriate amount and quantity of waste, since two key requirements for justified WtE use are [18]:

- Supply of municipal waste combustible fraction larger than $100,000 \mathrm{Mg} /$ year.

- The lower calorific value (LCV) must be, on average, at least $7000 \mathrm{~kJ} / \mathrm{kg}$ and never fall below $6 \mathrm{MJ} / \mathrm{kg}$.

All plants depicted on Fig. 2 will have capacity, larger or comparable, to $100000 \mathrm{Mg}$ per year. Moreover these plants will most likely process wastes with LCV above $5800 \mathrm{~kJ} / \mathrm{kg}$, which is an adopted condition for autothermic municipal waste combustion (i.e. without firing additional fuel) [19]. Municipal waste rich in plastics and paper, like in cities of Kraków $(8800 \mathrm{~kJ} / \mathrm{kg}$ ) and Poznań $(8400 \mathrm{~kJ} / \mathrm{kg})$, can easily have LCV larger than $7000 \mathrm{~kJ} / \mathrm{kg}$. What is more, in exceptions, municipal waste mechanical sorting can be used to raise waste average calorific value before energy recovery [15]. Therefore combustible fractions of municipal waste from Polish big cities are of high interest for the WtE industry both in terms of amount and fuel properties.
Present deficiency of the WtE infrastructure in Poland is striking because even before World War II such plants were combusting Polish municipal waste. The first facility of this type was the plant built in Warsaw in 1912 which was working till World War II. The second was the plant in Poznań which was built in 1927 and it was the most modern facility of this type in Central Europe [18]. However, exploitation of this plant was also interrupted by the outbreak of World War II, but after war it was rebuilt, and from 1955 to 1957 plant burned waste again.

During 1906s Western European countries and other high income countries had started to build WtE plants on mass scales. In the late 1970 s political measures towards even stricter reduction of allowable emissions of dioxins and other important pollutants, such as heavy metals, chlorine, sulfur dioxide, carbon monoxide and particulate matter have been taken. As a result of new emission standards WtE industry, worldwide, it has been transformed from a past major emitter of pollutants to modern clean power generators, which are subject to the most stringent emission standards from almost all branches of industry [19].

While behind western boundary WtE industry was still under development, at the same time the issue of municipal waste energy recovery was completely neglected in Poland and in second half of $20^{\text {th }}$ century only one $\mathrm{WtE}$ plant was built (i.e. ZUSOK). After the political transformation in 1989 the implementation of new Polish WtE projects plants was still postponed by subsequent government cadences, despite the obvious political and economic benefits of waste energy recovery. For example, WtE plant for Cracow has been considered since 1992 [20] and the indicative list of WtE projects in the Operational Programme Infrastructure and Environment (OPIE) for the years 2007 to 2013, takes into account 12 new WtE plants to build in Poland during the 2007-2014 period [21].

The explanation of such delays in the development of Polish WtE industry may be high investment costs which, are much higher for $\mathrm{WtE}$ than for any other waste disposal method [15]. For aforementioned $12 \mathrm{WtE}$ plants included in OPIE, total investment costs were estimated on 6,067 billion PLN [21].Such high costs make WtE plants one of the most expensive investments in Polish environment protection policy. However, EU financial funding in the form of grants is helping in the implementation of this type of projects. EU financial support for 12 plants from OPIE was estimated as $61 \%$ of total investment costs [21]. Share of EU funding together with the most important dates in the implementation of the 6 most advanced new Polish WtE projects are presented in the Table 2.

EU financial support together with the fact that waste management is a highly regulated industry can be key to the explanation of why $\mathrm{WtE}$ is nowadays being exploited more intensively in Poland. Additionally, EU energy targets establish a sustained market pull toward renewable energy, including energy recovered from waste. Those two aspects imply that there exist additional factors which may affect how waste management practices will evolve and ultimately influence the Polish incentive to invest in WtE [7]. 
Table 2. Summary of ongoing WtE projects together with costs and key dates.

\begin{tabular}{|c|c|c|c|c|c|c|}
\hline & $\begin{array}{c}\text { Throughput } \\
\text { [Mg/year] }\end{array}$ & $\begin{array}{c}\text { Contract value } \\
\text { [million PLN] }\end{array}$ & $\begin{array}{c}\text { EU funding } \\
\text { [million PLN] }\end{array}$ & $\begin{array}{c}\text { Environmental } \\
\text { decision }\end{array}$ & $\begin{array}{c}\text { Date of } \\
\text { construction } \\
\text { commencement }\end{array}$ & $\begin{array}{c}\text { Date of obtaining } \\
\text { work permission }\end{array}$ \\
\hline BYDGOSZCZ & 180000 & 436 & 262 & 23.11 .2010 & 30.09 .2013 & 28.08 .2015 \\
\hline KRAKÓW & 220000 & 797 & 372 & 14.01 .2011 & 06.11 .2013 & 29.09 .2015 \\
\hline BIALYSTOK & 120000 & 410 & 197 & 30.05 .2011 & 09.12 .2013 & 05.05 .2016 \\
\hline SZCZECIN & 150000 & 666 & 245 & 21.06 .2011 & 16.12 .2013 & 18.12 .2015 \\
\hline KONIN & 94000 & 364 & 150 & 03.08 .2012 & 03.11 .2013 & 14.12 .2015 \\
\hline POZNAŃ & 210000 & 925 & 330 & 17.10 .2013 & 30.04 .2013 & 06.05 .2016 \\
\hline
\end{tabular}

However, EU on the one hand provides a reliable and relevant, financial and technical support, but on the other hand through its law, is necessary to use in new WtE plants advanced, efficient and expensive exhaust flue gas cleaning systems. Division of costs on example of Konin WtE plant for is shown on Figure 3.
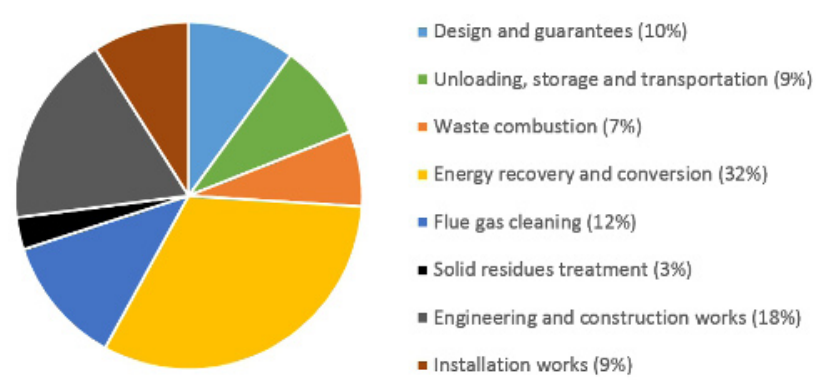

Figure 3. Division of WtE plant investment costs on particular segments [22].

Despite the financial, issues another reason of Polish WtE implementation delays, can be opposition of local communities against construction of waste recovery facilities near residential areas (NIMBY syndrome). However according to data from the study [16] up to $73 \%$ inhabitants of Polish cities would agree to build a WtE plant in their neighborhood, therefore positive trend regarding $\mathrm{WtE}$ perception among citizens may be observed.

\section{Current Polish WtE Projects}

In order to minimise environmental impacts and ensure safe operation, all of Polish WtE plants have been prepared on basis of contemporary standards regarding their design, construction and operation. Reference information for WtE plants are included in BREF documents [23], which are a reliable source of information and recommendations about clean, effective and secure design for municipal waste energy recovery. Such design is based on proven techniques and technologies but also on the way in which such facilities should be operated.
Nowadays, combustion is the leading process of energy recovery from waste, what usually involves burning waste on the moving grate.

Alternative thermal treatment technology for treating municipal wastes (e.g., fluidized bed, pyrolysis, and gasification), mainly due to the municipal waste physical and chemical properties, have not proven in practice to have as high energy efficiencies as the classical grate-based WtE plants [19]. Table, which presents a summary of technical parameters for most recent Polish WtE plants, shows that the dominant type of used combustion technology is moving grate technology. Moving grate is the leading solution in WtE facilities, mainly because of its simplicity, reliability and energy efficiency [24] (for example, approx. 85\% of market share in France and Germany [13]).

All of 6 abovementioned plants have assumed availability equal to approx. 8000 hours per year, what is standard requirement for the modern $\mathrm{WtE}$ plants. The operation hours are one of the most important factors for the plant owner, because it has dominant influence on yearly plant income [25]. This fact cause that investors tend to choose well-proven technology, what additionally explains why only grate technology is used to burn Polish municipal waste. What is more all of the examples presented in Table uses state-of-the-art technologies in flue gas cleaning installation what ensures very insignificant environmental impact.

Polish environment protection infrastructure will improve and expand significantly when all of the WtE plants from Table 2 will work with nominal performance in terms of waste disposal and power production. Operation of those medium-scale plants will increase national energy security and will broaden implementation of suitable development rules. The total planned capacity of abovementioned six WtE plants is approximately equal to one million tons per year, which in comparison to the total amount of municipal waste generated in Poland (i.e. 11 330,4 thousand tons in 2014 [2]) shows significant increase in recovery methods in Polish municipal waste management, what is presented in Figure 4.

${ }^{\mathrm{a} C}$ Corresponding author: cyranka@agh.edu.pl 
Table 3.Summary of ongoing $\mathrm{WtE}$ projects - technical data.

\begin{tabular}{|c|c|c|c|c|c|c|c|c|c|c|c|}
\hline WtE Plant & Contractor & 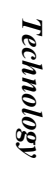 & 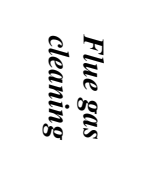 & ミ & 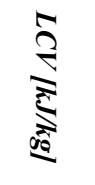 & 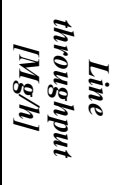 & 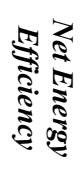 & $\gtrsim$ & 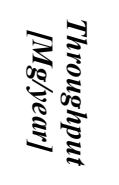 & 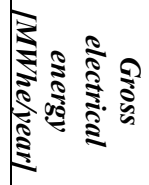 & 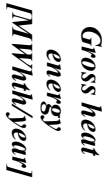 \\
\hline BYDGOSZCZ & $\begin{array}{c}\text { ASTALDI S.p.A., } \\
\text { Termomeccanica } \\
\text { Ecologia }\end{array}$ & \multirow{6}{*}{ 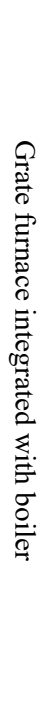 } & $\begin{array}{l}\text { Wet + semi- } \\
\text { dry / SNCR }\end{array}$ & 7800 & 8500 & $2 \times 11,5$ & 0,64 & 0,89 & 180000 & 71760 & 216060 \\
\hline KRAKÓW & $\begin{array}{l}\text { Posco Engineering \& } \\
\text { Construction }\end{array}$ & & $\begin{array}{l}\text { Semi-dry / } \\
\text { SNCR }\end{array}$ & 8100 & 8800 & $2 \times 14,1$ & 0,60 & 0,80 & 220000 & 67860 & 273000 \\
\hline BIALYSTOK & $\begin{array}{l}\text { Budimex S.A., } \\
\text { Keppel Seghers }\end{array}$ & & $\begin{array}{l}\text { Semi-dry / } \\
\text { SNCR }\end{array}$ & 8050 & 7500 & $1 \times 15,5$ & 0,58 & 0,79 & 120000 & 31258 & 118200 \\
\hline SZCZECIN & $\begin{array}{c}\text { MOSTOSTAL S.A, } \\
\text { RAFAKO S.A } \\
\text { Hitachi PE } \\
\end{array}$ & & Wet /SNCR & 7500 & 10500 & $2 \times 10,0$ & 0,50 & 0,75 & 150000 & 71439 & 159984 \\
\hline KONIN & $\begin{array}{c}\text { Integral Eng., } \\
\text { ERBUD S.A., Introl } \\
\text { S.A. }\end{array}$ & & $\begin{array}{l}\text { Semi-dry / } \\
\text { SNCR }\end{array}$ & 7800 & 8500 & $1 \times 12,05$ & 0,75 & 0,94 & 94000 & 26602 & 148200 \\
\hline POZNAŃ & $\begin{array}{c}\text { SITA ZE, Hitachi ZI, } \\
\text { Hochtief }\end{array}$ & & $\begin{array}{l}\text { Semi-dry / } \\
\text { SNCR }\end{array}$ & 7800 & 8400 & $2 \times 13,5$ & 0,66 & 0,89 & 240000 & 78000 & 312000 \\
\hline
\end{tabular}

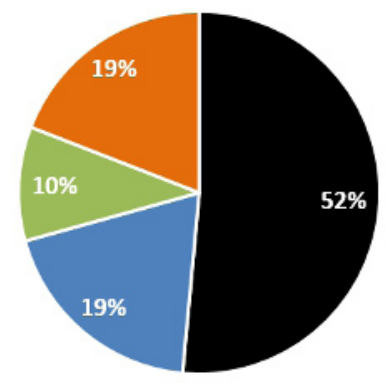

Landfilling = Recycling = Biological treatment = WtE Figure 4. Prognosis of waste management in 2016 (based on [2]).

Unfortunately, in the case of energy production, potential impact of the described six WtE plants is not so significant, i.e. those plants can cover only approx. $0.2 \%$ of Polish electricity consumption $(161,1$ $\left.\mathrm{TWh}_{\mathrm{e}}[26]\right)$, and approx. $2.0 \%$ of the heat demand $(275,1$ $\mathrm{PJ}_{\text {th }}$ [26]). However, if we consider energy production prognosis in the criteria of renewable energy sources it can be concluded that waste energy recovery will become an important part in Polish "green" energy market, especially in terms of heat production. This is confirmed by results presented onFigure 5 and Figure 6 .

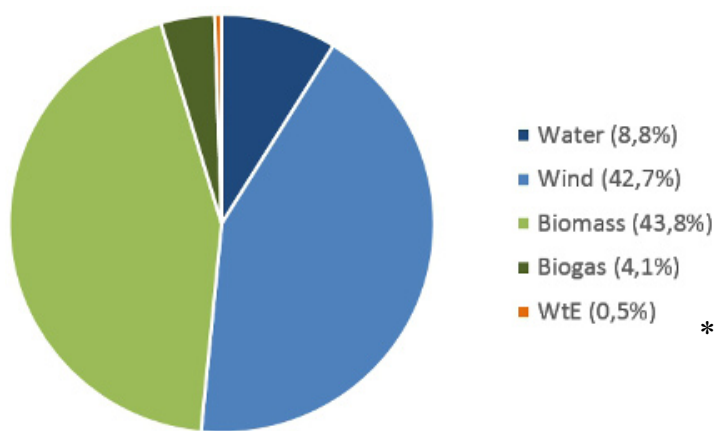

Figure 5. Prognosis of electricity generation from renewable sources in 2016 (based on [27]).

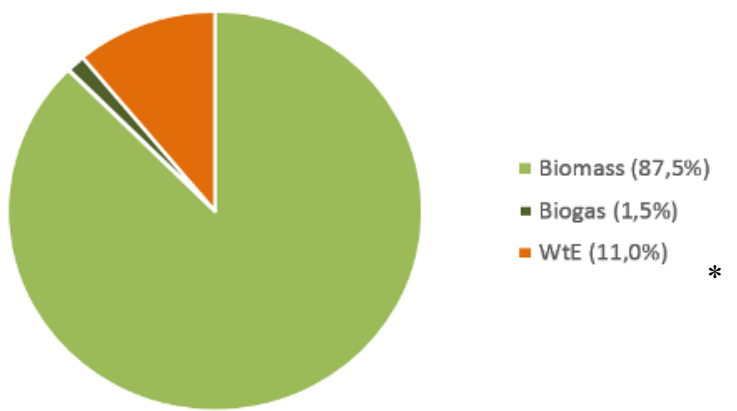

Figure 6. Prognosis of heat generation from renewable sources in 2016 (based on [27]).

*- Based on recognition of $50 \%$ energy produced in Waste-to-Energy as renewable

${ }^{\mathrm{a} C}$ Corresponding author: cyranka@agh.edu.pl 
Every Polish WtE plant design (especially designs for six plants described here) assume operation in cogeneration, i.e. synergic production of both electricity and thermal energy. This is because it turns out that the most effective work of plant combusting municipal waste, and therefore plant that is usually located in densely populated areas, is a combination of electricity generation with production of heat which meet the needs of nearby external users, i.e. district heating network or industrial plants [28]. This is caused by fact that in WtE plants far more economically justified is to generate a certain amount of thermal energy than the same amount of electricity. It is so because of basic thermodynamic laws and fact that parameters of steam produced in $\mathrm{WtE}$ boiler are significantly reduced due to the highly corrosive nature of the flue gases.

The standard WtE grate-based combustion technology is using steam parameters of $40 \mathrm{bar} / 400{ }^{\circ} \mathrm{C}$. Typically, these plants exports $500 \mathrm{kWh}$ of electricity per ton of waste [6]. Average efficiency of energy production in European WtE plant is equal to approx. $26.1 \%$ in case of producing only electricity, $77.2 \%$ in case of producing only heat and $52.1 \%$ in case of combined heat and power production [29]. Producing both heat and electricity causes that energy efficiencies of all the mentioned six Polish WtE plants is well above the standard $26.1 \%$ (for only electricity production). Energy efficiency is a key parameter for reducing the overall cost as well as the environmental impact of waste energy recovery facilities and it is therefore an important direction of $\mathrm{WtE}$ research and development [19].

It can be expected th0at minimum standards for energy efficiency will be raised over time, what has already been implemented by the EU which requires that all new $\mathrm{WtE}$ plants must have a sufficiently high energy efficiency indicator, i.e. so called R1 factor. R1 factor is performance indicator introduced by European Union Directive 2008/98/WE [3], indicating the viability and rationality of waste energy recovery process and is used to determine the efficiency of waste chemical energy conversion potential.

According to EU law, R1 value obligatory for WtE plants conducting energy recovery process (R1) must be equal to or greater than 0.65 . If $\mathrm{R} 1$ value is smaller than 0.65 , then WtE plant conduct waste disposal (D10) which is not considered as waste energy recovery. Most likely, when nominal performance parameters will be met, all Polish WtE projects listed in Table will fulfill above requirements during operation. This is mostly by using cogeneration in those plants, without which it would be difficult to meet required $\mathrm{R} 1$ factor value.

\section{Key Challenges \& Opportunities}

Ongoing operation of Polish WtE plants will be associated with a number of challenges and responsibilities that must be fulfilled in order to ensure full utilization of such plants.

The most important tasks for operators will include achievement of assumed availability and efficiency of the facility and all its segments. Of course WtE plant operation should be supported by appropriate optimization so that the beneficial effects of energy recovery will be maximized while ecological threats will be maintained on the minimal level. Uncertainties regarding waste feed (e.g. separate collections systems performance and effectiveness) and energy generation (e.g. heat demand and electricity price) are crucial parameters for evaluation and optimization of $\mathrm{WtE}$ projects. Unfortunately, those uncertainties make that new $\mathrm{WtE}$ facility planning is a very complex task [30].

Even more important than commercial use, step of WtE plant life, is beginning phase of exploitation, i.e. test runs, start-up and commissioning from contractor. All eventual malfunctions and mistakes in design and montage should be revealed latest on this phase. In addition, under the supervision of contractor, plant should be checked for meeting required technical parameters. Another important aspect of preparing WtE plant for regular operation is appropriate selection and training of the crew, which will take care about safe, clean and efficient waste energy recovery during plant operation.

When plant and operators are prepared to run municipal waste energy recovery then it is necessary to ensure incoming waste stream of sufficient quantity and quality. Mass and calorific value of waste must be adequate to boiler design and waste management regime inside plant, which cannot operate in suitable manner when there is too much or not enough of wastes or their proprieties hinder operation of plant subsystems like waste storage and transportation.

WtE plants can be a useful sink, not only for Polish municipal waste, but also for alternative fuels produced from such waste. Current problem is the lack of sufficient infrastructure for disposal of combustible fraction coming from the mechanical-biological waste treatment installations (MBT). Today only available recipient of fuels produced from wastes (RDF/SRF) are cement producing facilities which are able to dispose less than $20 \%$ of combustible fraction possible to produce in Poland [31].

Alternative fuels may be input in coal-fired boilers and experience indicates that those fuels can contribute up to $30 \%$ of total energy input into such boilers [5]. Using coal for energy generation is in Poland important part of energy/fuel strategy, i.e. coal has approx. 54\% share in total energy production and import [26]. However typical cofiring rate for solid fuel is $3 \%$ or less, because of metal particles and glass fines which may pose combustion problems, high chloride concentrations which may induce boiler tube corrosion and high levels of ash production which may create residuals management problems [5]. Hence use of municipal waste in the Polish conventional energy industry is rather avoided and seen as unnecessary evasion of new $\mathrm{WtE}$ plants development.

In accordance with the suitable development principles energetic usage of coal, as every natural resource, should decrease. Recently built WtE plants replaces an estimated 0.4 tons of coal for electricity generation [32]. Replacement of coal and other fossil fuels, with regionally produced municipal waste without a doubt will increase Polish energy safety.

Energy recovery from municipal waste is capable of displacing large amounts of fossil generation and even 
additional positive ecological effect occur when raw materials are recovered from the incoming waste and/or from combustion residuals [5]. Therefore, Polish WtE plants operators should optimize not only the energy recovery, but also maximize recovery of recyclable materials from combustion residues. Main goals for optimizing $\mathrm{WtE}$ plant in terms of solid residues management are [33]:

- Production of highly inert bottom ashes by adequate combustion control;

- Reduction of fly ashes amount by adequate primary air control;

- Achievement of excellent gas phase and fly ash burnout;

- Rendering the boiler and filter ashes inert and safe for disposal or even utilization;

- Management and safe disposal of the residues from the chemical gas cleaning systems.

Additionally, to technological and organisational challenges that lay before Polish WtE plant operators administrative challenges should be not forgotten. The large costs of this type facilities can attract unwanted political influence, so the local administration should ensure that the technology selection process is as transparent as possible, with all costs over the life of the facility considered [34]. What is more Polish waste managers, during implementation of WtE projects, should consider issues connected with [1]:

- Inadequate ownership of waste streams (Polish Waste Management System is during transformation process);

- Inadequate financial incentives (taxes, fees);

- Poor public awareness / participation;

- Inadequate number of collection points;

- Unreliable data regarding waste;

- Poor administrative capacity for adopting EU funds;

- Lack of public-private partnerships.

No less important than aspects enlisted above is the role of the $\mathrm{WtE}$ plant as facility providing society with information about modern waste recovery systems. WtE plants should present themselves to the public opinion as utilities bringing citizens a lot of tangible benefits improving environment in which they are living. Additional advantage, from citizen's point of view, is fact that due to development of the WtE sector there will be a significant increase in direct and indirect jobs aimed on operation and maintenance of such infrastructure (in 2011 only 50 persons were employed in polish $\mathrm{WtE}$ industry [35]).

Social information role of WtE plant can be realized mainly by: information campaigns, "open days" visits and especially by full transparency in the operation. Public education in terms of waste management is desirable, because waste managers need to select from among several challenging technology and better decisions are made when the public is part of the decision making process and supports waste management program [34].

WtE should be developed and located in waste management structures taking into account the principles of suitable development and waste hierarchy (Figure 1).
Although, there is a risk that European, and therefore Polish, waste policies and the dynamic of the waste system, will become stagnated in recycling/WtE, and even landfill oriented strategies, assigning a lower weight to top of the waste hierarchy [36]. This is particularly relevant in relation to idea of circular economy which contribute to "closing the loop" of product lifecycles through greater recycling and re-use and bring benefits for both environment and economy [37].

EU waste policy pushes for an economy where targets for prevention, reuse, recycling, recovery and landfill should move towards a circular economy, where waste that cannot be eliminated are turned into a resource. Realization of circular economy policy postulates will have great impacts on $\mathrm{WtE}$ facilities by limiting energy recovery to non-recyclable materials. This constraint may reduce the future development field of municipal waste energy recovery [7]. Implementation of such plans in Polish economy should affect decisions regarding the implementation of new plants and optimization of plants that are already operated.

\section{Conclusion}

Due to the low level of any forms of municipal waste recycling or recovery in Polish economy, the development of WtE infrastructure is highly desirable and should be immediately implemented in order to efficiently use energy from Polish municipal waste. Development of Polish WtE industry is right direction and it should be continued at all levels of the national administration.

Taking into account six new WtE plants, with a total capacity of 1 million tons, is a significant success and progress in the fields of municipal waste management and renewable energy sources in Poland. Additionally, experience gained during the entire cycle of projects realization should be used to improve even further implementation of waste recovery and recycling methods for Polish waste management system.

Energy recovered from waste without doubt is a very valuable kind of energy for the national grid, better for the environment than the energy gained from fossil fuels. Moreover, the operation of WtE plants not only provide a regional and renewable source of energy but is also improving Polish economy, especially in the environment protection criteria. Most important advantages resulting from operation of currently operating Polish WtE projects are listed below:

- Source of energy, some of which may be considered as derived from renewable energy sources;

- Reduction of fossil fuels use and increase of national energy security;

- Waste diversion from landfills and thus the environmental load reduction;

- Ability to conduct additional raw materials recovery (especially metals) from combusted waste;

- Adding experience and foundations for further implementation of suitable development rules in Polish waste management; 
- Public information role, explaining position and role of WtE in modern and sustainable waste management system.

However, in order to ensure tasks enlisted above, considerable responsibility will be placed on WtE plants operators. Such operators will have to implement appropriate organizational, maintenance and also optimizing measures for safe, efficient and stable $\mathrm{WtE}$ plant exploitation.

If six new Polish WtE plants will confirm their technical and operational indicators than national environment protection will be significantly improved, especially in cities and regions where $\mathrm{WtE}$ plants will be located. Operation of those plants, apart from the benefits associated with energy production, will also adjust Polish economy to contemporary standards and trends in the EU as well bring closer assumptions of circular economy. What is more, emergence of modern Polish WtE plants is also a great opportunity to change the mindset of local communities and change the public perception of municipal waste energy recovery in Poland.

\section{References}

1. A. Tonderski, ISWA (2013)

2. Główny Urząd Statystyczny (2015)

3. P. Aragonés-Beltrán, F. Chaparro-González, J.-P. Pastor-Ferrando, A. Pla-Rubio, Energy 66, 222238. (2014)

4. CEWEP, $(2009$

5. Electric Power Research Institute, Palo Alto, (2011).

6. J. J.E. Martin, R. Koralewska, A. Wohlleben, Waste Manage., 37, 147 (2015)

7. Coolsweep the 7th Framework Programme (2013

8. R. F. Sawyer, P. Combust. I. 32, 45 (2009)

9. GUS, Ludność. Stan i struktura ludności oraz ruch naturalny w przekroju terytorialnym. Data for 30 VI 2015 r. (2015)

10. Mazowiecki Ośrodek Badań Regionalnych (2015)

11. R. Oleniacz, Geo. Environ. Eng. 4, 25 (2014)

12. G. Wielgosiński, Międzynarodowa konferencja Zakłady termicznego przekształcania odpadów jako regionalne instalacje (2013)

13. International Solid Waste Association (2012)

14. G. Wielgosiński, Nowa Ener. 37, 17 (2014)

15. World Bank, What a waste: A global review of solid waste management (2012).

16. Deloitte, Fortum and 4P Research Mix, Gospodarka odpadami w Polsce - Wyzwania w świetle wymogów unijnych i zmian legislacyjnych, opinie społeczne i perspektywy (2011)

17. E. Den Boer, A. Jędrczak, Z. Kowalski, J. Kulczycka R. Szpadt, Waste Manage. 30, 369 (2010)

18. B. Kamuk, ISWA (2013)

19. L. Sieja, T. Pająk, Termiczne przekształcanie odpadów, jako niezbędny element systemu gospodarki odpadami komunalnymi dla dużych aglomeracji miejskich - podstawowe uwarunkowania, (2005)

20. Wikipedia, Spalarnia śmieci na Wilczaku w Poznaniu (2016)

21. M. Van Berlo, Renew. Energ. 1532 (2013)

22. A. Generowicz, J. Pauli Wilga, J. Sacharczuk, Aktualizacja wyboru lokalizacji zaktadu termicznego przekształcania odpadów na podstawie analizy wielokryterialnej, Krakowski Holding Komunalny S.A. (2009)

23. T. Pająk, Ocena dobiegających końca budów ZTPOK (2015)

24. MZGOK w Koninie, Budowa Zaktadu Termicznego Unieszkodliwiania Odpadów Komunalnych $w$ Koninie (2014)

25. IPPC, BREF Reference Document on the Best Available Techniques for Waste Incineration (2006)

26. M. Cyranka, M. Jurczyk, Agric. Eng., 20, 23 (2016)

27. O. Hedegaard Madsen, Proceedings of the 15th Annual North American Waste to Energy Conference (2007)

28. GUS, Energy - 2015 (2015)

29. GUS, Energia ze źródeł odnawialnych w 2014 r., (2015)

30. M. Cyranka, M. Jurczyk, Energia i Paliwa (2015)

31. D. Reimann, Energy Report III (2012)

32. R. Somplák, T. Ferdan, M. Pavlas, P. Popela, Appl. Therm.l Eng. 61, 106 (2013)

33. A. Majcherczyk, Instalacja Termicznego Przekształcania Odpadów jako alternatywa dla energetyki przemysłowej (2015)

34. N. J. Themelis, C. Mussche, Energy And Economic Value Of Municipal Solid Waste (Msw), Including Non-Recycled Plastics (Nrp), Currently Landfilled In The Fifty States (2014)

35. J. Vehlow, H. Seifert, IEA Bioenergy (2012)

36. D. Hoornweg, P. Bhada-Tata, Waste Wise (2014)

37. EurObser'ER, Renewable Municipal Waste Barometer (2014)

38. M. Mazzanti, R. Zoboli, Resour. Conserv. Recy. 52, 1221 (2008)

39. Environment Directorate-General of the European Commission, Circular Economy Strategy (2016) 